\title{
PEMETAAN AKUIFER AIRTANAH DI WILAYAH KAMPUS UNSRAT MANADO DENGAN MENGGUNAKAN METODE GEOLISTRIK TAHANAN JENIS
}

\author{
Sweetny Steria Sulu ${ }^{1)}$, As'ari ${ }^{1)}$, Seni Herlina Juwita Tongkukut ${ }^{1)}$ \\ ${ }^{1)}$ Program Studi Fisika, FMIPA, UNSRAT \\ e-mail: sulusweetny@gmail.com, as.ari2222@yahoo.co.id, linashafii@yahoo.com
}

\begin{abstract}
ABSTRAK
Penelitian ini bertujuan untuk memetakan keberadaan akuifer air tanah di Jl. Kampus Selatan Kecamatan Sario Kota Manado berdasarkan resistivitas batuan bawah permukaan hasil eksplorasi geofisika dengan metode geolistrik tahanan jenis. Penelitian ini terdiri dari 18 titik sounding yang terbagi dalam 4 lintasan dimana setiap lintasan dibuat model struktur lapisan tanah dibawah permukaan. Kondisi lapisan akuifer airtanah ini dapat dieksplorasi dengan metode geofisika yang dapat digunakan untuk menyelidiki struktur bawah permukaan berdasarkan perbedaan resistivitas batuan. Hasil eksplorasi ini kemudian diolah dengan menggunakan software IP2WIN untuk melihat data lapisan tanah berdasarkan nilai resistivitasnya (2D) dan pesebaran titik - titik terdapatnya akuifer airtanah. Berdasarkan model struktur lapisan tanah di bawah permukaan ini diperoleh lapisan akuifer airtanah yang berupa akuifer airtanah dangkal dengan nilai resistivitas $\rho$ $\leq 14,5 \Omega \mathrm{m}$. Lapisan akuifer airtanah yang berupa akuifer airtanah dangkal permukaan dengan kedalaman 2 meter pada titik sounding 3. Kedalaman 3 meter pada setiap titik sounding. Terdapat akuifer airtanah dangkal dalam pada kedalaman 10 meter dititik sounding 15.
\end{abstract}

Kata kunci : Akuifer airtanah, geolistrik tahanan jenis, software IP2WIN, struktur lapisan tanah.

\section{THE MAPPING OF GROUNDWATER AQUIFER IN UNSRAT (MANADO BY USING THE GEO ELECTRIC OF RESISTIVITY METHOD}

\begin{abstract}
This research is intebded to map the existence of groundwater aquifer at Jl. Kampus Selatan Kecamatan Sario in Manadi city, based on resistivity of subsurface rock as exploration result is of geophysics by geo electric methode. The research consist of 18 sounding points which divided in 4 lines, that a model of this aquifer can be explored by geophysics method. This method can be use to see into subsurface structure based on the difference of rocks resistivity. This exploration result then proceeded by using IP2WIN software to see ground layers data based on resistivity values (2D) and the spread of the points in which the groundwater aquifer exists. Based on this subsurface ground layers structure, the groundwater aquifer layer of shallow groundwater is acquired with $\rho \leq 14,5 \Omega \mathrm{m}$ resistivity values. This can be found on sounding point 3 at depth of $2 \mathrm{~m}$. Aquifer with dept of $10 \mathrm{~m}$ found in sounding point 15 .
\end{abstract}

Keyword : groundwater aquifer, geo electric resistivity, IP2WIN software, ground layers structure.

\section{PENDAHULUAN}

Air tanah merupakan salah salah satu komponen dalam peredaran air di bumi yang dikenal sebagai siklus hidrologi (Minarto, 2011) dimana air yang sering digunakan sehari - hari telah melalui proses penguapan (precipitation) dari laut, danau, maupun sungai, lalu mengalami kondensasi di atmosfer, dan kemudian menjadi hujan yang turun ke permukaan bumi. Air hujan yang turun di permukaan bumi tersebut ada yang langsung mengalir di atas permukaan bumi (run off) dan ada yang meresap ke bawah permukaan bumi (infiltration) (Abdulrahman dalam Sadjab, 2012). Airtanah sampai saat ini masih menjadi solusi untuk mengatasi permasalahan 
kekurangan air bersih. Selain murah airtanah juga mudah di dapat, namun tidak selalu tersedia dalam jumlah yang melimpah (Irjan, 2012). Pembangunan gedung - gedung baru termasuk rencana pembuatan rumah sakit di kampus UNSRAT akan membutuhkan cadangan air yang banyak dalam jangka waktu yang panjang, untuk itu perlu adanya identifikasi potensi cadangan airtanah dan daerah pesebarannya di bawah permukaan kampus Unsrat. Pertumbuhan penduduk merupakan salah satu faktor pemicu kebutuhan air yang semakin meningkat. Semakin meningkat kebutuhan air bersih, maka eksplorasi airtanah juga semakin besar (Hadi, dkk. 2009). Metode ini digunakan untuk memetakan keberadaan akuifer airtanah di FMIPA, Fakultas Pertanian dan sekitarnya di Universitas Sam Ratulangi. Keunggulan dari penelitian ini adalah memberikan informasi yang penting tentang keberadaan air dilingkungan unsrat yang belum pernah diteliti sebelumnya oleh pihak manapun dan software yang digunakan sangat membantu menginterpretasikan keberadaan airtanah pada setiap titik sounding dengan software IP2WIN dan pola sebaran air dengan software Surfer 8 .

\section{METODE GEOLISTRIK}

Metode tahanan jenis (Resistivitas) adalah salah satu dari kelompok metode geofisika yaitu metode geolistrik untuk mempelajari keadaan bawah permukaan dengan cara mempelajari sifat aliran listrik di dalam batuan di bawah permukaan bumi berdasarkan perbedaan resistivitas batuan. Prinsip kerja dari metode resistivitas adalah mengalirkan arus listrik kedalam dua elektroda arus, kemudian beda potensialnya diukur melalui dua elektroda potensial sehingga nilai resistivitasnya dapat dihitung. Resistivitas (tahanan jenis) merupakan suatu besaran yang menunjukkan tingkat hambatan terhadap arus listrik dari suatu bahan. Berdasarkan letak (konfigurasi) elektroda potensial dan arus, dikenali beberapa jenis konfigurasi polarisasi terimbas antara lain :
1. Konfigurasi pole-pole

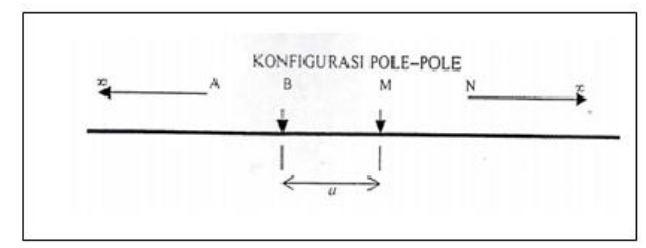

2. Konfigurasi Wenner

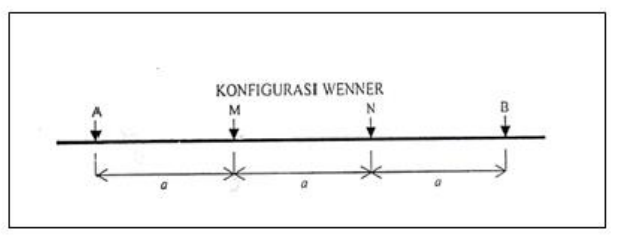

3. Konfigurasi Schlumberger

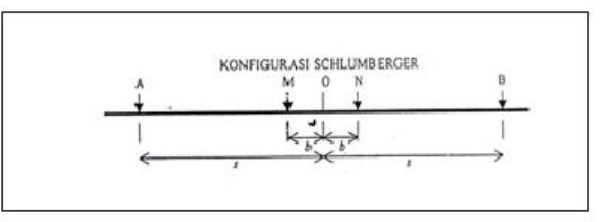

Jenis - jenis konfigurasi metode geolistrik Metode geolistrik resistivitas bekerja karena pengukuran beda potensial titik - titik di permukaan bumi yang diproduksi dengan langsung mengalirkan arus ke bawah permukaan. Hal ini bermanfaat untuk menentukan distribusi resistivitas di bawah permukaan dan kemudian digunakan untuk interpretasi material - material yang ada di dalam bumi.

$$
J=\sigma . E
$$

Dimana : $\mathrm{J}=$ Rapat Arus (Ampere $/ \mathrm{m}^{2}$ )

$$
\sigma=\operatorname{Konduktivitas}\left(\Omega \mathrm{m}^{-1}\right)
$$

$\mathrm{E}=$ Medan listrik $($ Volt $/ \mathrm{m})$

Dari persamaan 2.1 dapat menjadi persamaan dalam teori hukum ohm dimana :

$$
V=I . R
$$

Sehingga menjadi :

$$
\rho=\frac{\pi s^{2}}{2 b}\left(\frac{\Delta V}{I}\right)
$$

\section{METODE PENELITIAN}

Penelitian ini dilaksanakan pada letak geografis FMIPA UNSRAT dan sekitarnya serta di Fakultas Pertanian UNSRAT pada $\left(1^{\circ} 27^{\prime} 34,20^{\prime \prime} \quad-1^{\circ} 27^{\prime} 25,40^{\prime \prime}\right)$ LU

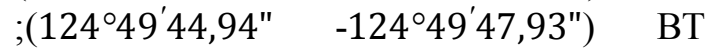


dengan menggunakan metode geolistrik konfigurasi Schlumberger, pengambilan data dilakukan pada 21 Oktober 2013 sampai 21 November 2013. Alat dan bahan yang digunakan dalam penelitian ini adalah komputer (Software IP2WIN dan software surfer 8), 1 set resistiviti meter GEPS 2000, dan 1 unit GPS. Bahan yang digunakan adalah peta geologi, stratigrafi Manado dan Google earth.

\section{HASIL DAN PEMBAHASAN}

Penelitian eksplorasi geofisika dengan metode geolistrik konfigurasi Schlumberger ini dilakukan di FMIPA UNSRAT dan sekitarnya serta di Fakultas Pertanian UNSRAT jalan Kampus Kleak yang Secara geografis lokasi penelitian terletak pada $1^{\circ} 27^{\prime} 34,20^{\prime \prime}$ - $1^{\circ} 27^{\prime} 25,40^{\prime \prime}$ LU dan $124^{\circ} 49^{\prime} 44,94^{\prime \prime}$ - 124 ${ }^{\circ} 49^{\prime} 47,93^{\prime \prime}$ BT.

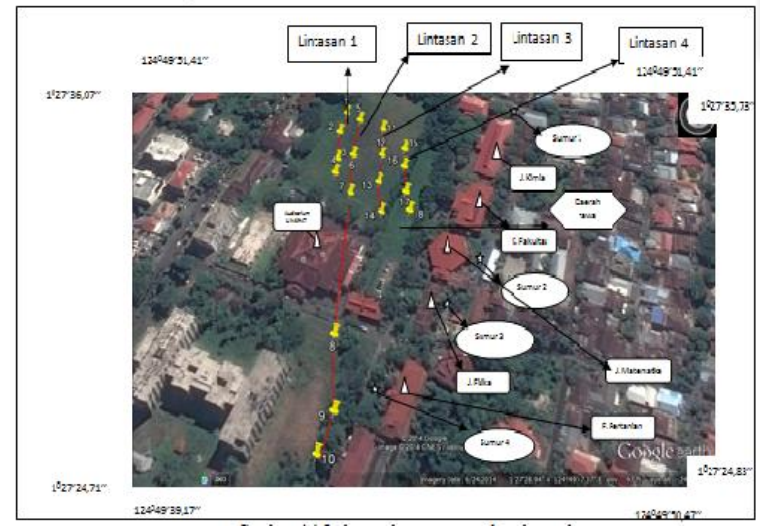

Gambar 1 Lokasi titik pengamatan daerah penelitian

Gambar 1 diambil dari peta Google earth. Kondisi daerah penelitian adalah datar, terdapat rawa pada titik 17 dan 18 , bangunan - bagunan kampus dan auditorium. Tanda bintang menunjukkan tentang keberadaan sumur air disekitar lokasi penelitian dimana terdapat 4 sumur yang tersebar pada Jurusan Kimia (sumur 1), Jurusan Matematika (Sumur 2), Jurusan Fisika (sumur 3), dan Fakultas Pertanian (sumur 4). Tanda segitiga menunjukkan Fakultas, jurusan dan auditorium.
Tabel 2 Nilai Resistivitas Batuan menurut Roy, E., (1984)

\begin{tabular}{|c|c|c|}
\hline $\mathrm{N}_{0}$ & Jenis Batuan & Resistivitas $(\mathrm{\Omega m})$ \\
\hline 1 & Lempung & $1-100$ \\
\hline 2 & Lanau & $10-200$ \\
\hline 3 & Batu Lumpur & $3-70$ \\
\hline 4 & Kuarsa Resistivitas & $10-2 \times 10^{8}$ \\
\hline 5 & Batu Pasir & $1-1000$ \\
\hline 6 & Batu Kapur & $100-500$ \\
\hline 7 & Lava & $100-5 \times 10^{4}$ \\
\hline 8 & Airtanah & $0,5-300$ \\
\hline 9 & Breksi & $75-200$ \\
\hline 10 & Andesit & $100-200$ \\
\hline 11 & Tufa & $20-100$ \\
\hline 12 & Konglomerat & $2 \times 10^{3}-1 \times 10^{4}$ \\
\hline
\end{tabular}

\section{Pengolahan IP2WIN Pada Lintasan Pertama}

Hasil pengolahan data dengan software IP2WIN pada lintasan 1 merupakan penggabungan titik sounding $1,2,3$, dan 4 seperti pada Gambar 2.

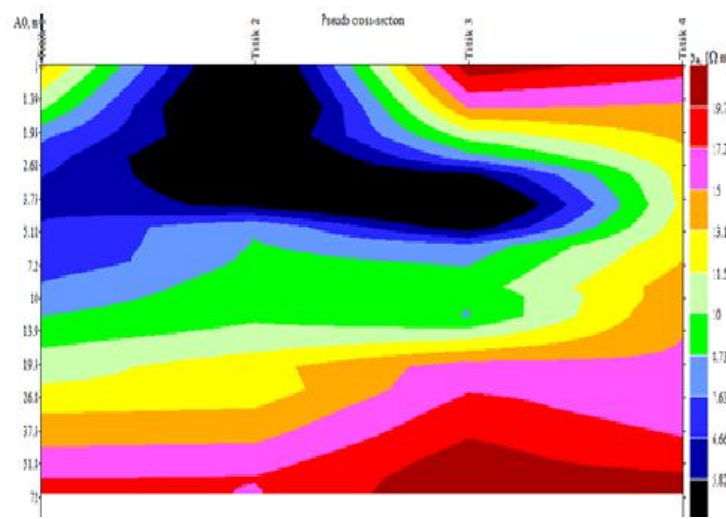

Gambar 2 Hasil pengolahan IP2WIN di lintasan 1 terdiri dari titik sounding 1, 2, 3 dan 4

Gambar 2 merupakan hasil pengolahan data lintasan satu merupakan gabungan antara titik sounding 1 sampai 4 . Daerah yang diduga memiliki airtanah dangkal adalah pada titik 3 dan 4 citra warna hitam. Citra warna merah, ungu, kuning, dan oranye merupakan lapisan airtanah rembesan. Pada titik 1 sampai 3 pada kedalaman 1 sampai 5,18 meter citra warna hitam dan biru diduga merupakan jenis tanah lembab yang berpotensi terdapat akuifer airtanah pada citra warna hitam dan merupakan airtanah rembesan pada citra 
warna biru, dimana air yang meresap didalam lapisan pada citra warna biru akan mengalir kelapisan selanjutnya yang akan meresap kelapisan bawah. Rembesan air yang berasal dari titik 1 sampai 4 sampai pada kedalaman 51,8 sampai 72 meter dengan citra warna ungu yang memiliki nilai resistivitas $\quad 17,2 \Omega \mathrm{m} \quad$ diinterpretasikan sebagai lapisan batuan tufa kasar dan lapisan batuan tufa yang berpotensi sebagai akuifer airtanah dalam yang bersifat sebagai airtanah rembesan. Citra warna hitam pada titik 2 dan 3 merupakan lapisan akuifer airtanah dengan debit air yang cukup besar. Titik - titik soundingpada lintasan ini diduga kuat memiliki akuifer airtanah dengan debit yang besar ada pada citra warna hitam dan pada citra warna yang lain seperti biru, hijau dan kuning merupakan lapisan yang memiliki lapisan airtanah tetapi bersifat rembesan dimana pada saat musim kemarau yang berkepanjangan dugaan kuat lapisan ini akan mengalami kekurangan bahkan kekeringan air.

\section{Pengolahan IP2WIN Pada Lintasan Kedua}

Hasil pengolahan data dengan software IP2WIN pada lintasan 2 merupakan penggabungan titik sounding $5,6,7,8,9$, 10 seperti pada gambar 4.8 yang menjelaskan tentang kondisi lapisan tanah disetiap titik yang berpotensi terdapat airtanah berdasarkan interpretasi citra warna dimana setiap warna memiliki nilai resistivitas yang berbeda - beda dan menjelaskan tentang citra warna hitam merupakan lapisan yang memiliki nilai resistivitas yang paling kecil dibandingkan dengan warna yang lainnya. Posisi lintasan ini terletak pada 20 meter antara lintasan 1 dan lintasan 3. Titik sounding 8. 9 dan 10 terletak di depan Fakultas Pertanian UNSRAT.

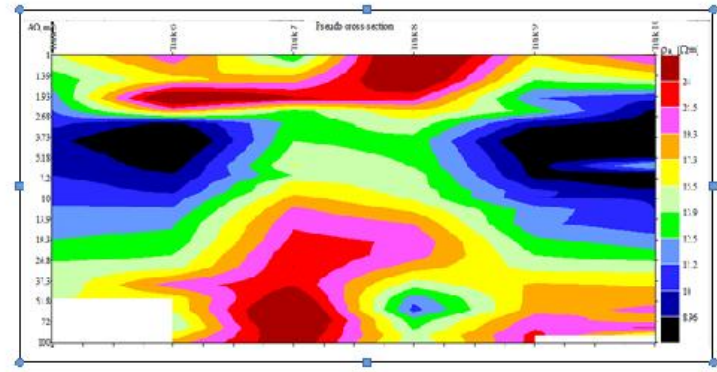

Gambar 3 Hasil pengolahan IP2WIN di lintasan 2 terdiri dari titik sounding 5, 6, 7, 8, 9 dan 10.

Gambar 3 merupakan hasil pengolahan data dengan IP2WIN untuk lintasan 2 yang memiliki 6 titik sounding. Titik sounding8, 9 dan 10 ini merupakan daerah tibunan rawa dan titik sounding 9 terletak sekitar 15 meter dengan lokasi sumur air 4 yang berada di depan Fakultas Pertanian. Kedalaman air pada sumur 4 adalah 2 meter dari permukaan tanah. Daerah pada lintasan kedua ini diduga berpotensi akuifer airtanah pada kedalaman 37,3 sampai 100 meter pada titi sounding 7 .

Citra warna biru dengan nilai resistivitas $10 \Omega \mathrm{m}$ diduga memiliki kemampuan meloloskan air dikarenakan jenis tanah yang lembab sehingga bersifat sebagai lapisan tanah yang merembeskan air pada lapisan berikutnya. Citra warna oranye dan kuning merupakan lapisan aluvium yang tersusun atas batuan sedimen berongga sehingga memiliki kemampuan meloloskan air.rembesan air yag mengalir dari setiap titik sounding sampai pada delaman 100 meter. Lintasan dua ini memiliki lapisan kedap air yaitu pada citra warna hitam dengan nilai sehingga berpeluang untuk mendapatkan air dengan debit yang besar dan didukung dengan lapisan pada citra warna yang lain yang bersifat merembeskan air.

\section{Pengolahan IP2WIN pada lintasan ketiga}

Hasil pengolahan data dengan software IP2WIN pada lintasan 3 merupakan penggabungan titik sounding $11,12,13,14$ seperti pada gambar 4.3. 


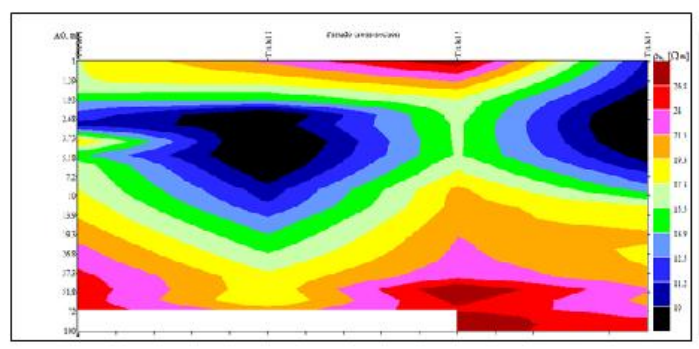

Gambar 4 Hasil pengolahan IP2WIN di lintasan 3 terdiri dari titik sounding 11, 12, 13 dan 14

Lokasi penelitian yang berdasarkan informasi dan tinjauan langsung sekitar 70 meter dari titik sounding 11 disamping jurusan Biologi FMIPA UNSRAT terdapat sumur air ( sumur 1) dengan kedalaman sumur 6 meter dari permukaan dan terdapat air pada kedalaman 3 meter dari permukaan sumur. Informasi yang ada pada saat musin kemarau dan penggunaan air yang banyak mengakibatkan debit air yang ada berkurang sampai kedalaman 6 meter dari permukaan sumur. Dugaan kuat sumur air ini pada kedalaman 3 sampai 7 meter merupakan akuifer airtanah yang diakibatkan oleh rembesan air pada lapisan sekitarnya.

Gambar 4 merupakan hasil pengolahan data dari lintasan 3 untuk titik sounding 11 sampai titik sounding 14. Daerah pada lintasan 3 ini ditemukan lapisan akuifer airtanah pada kedalaman 3 sampai 7 meter. pada titik sounding 11 dan titik sounding 12 dengan citra warna kuning da oranye merupakan lapisan aluvium. Lapisan pada citra warna biru disetiap titik sounding pada lintasan 3 ini merupakan lapisan sedimen berpori dan lapisan tanah lembab sehingga memiliki kemampusn meloloskan air yang besar. Citra warna hitam pada lintasan tiga ini diduga kuat merupakan lapisan kedap air dengan debit air yang cukup besar bisa dilihat pada titik 12 dan 14 dan didukung dengan keadaan sekitar yang merupakan daerah rawa dan terdapatnya beberapa sumur air pada kedalaman 3 meter di lokasi pengambilan data.

\section{Pengolahan IP2WIN Pada Lintasan 4}

Hasil pengolahan data dengan software IP2WIN pada lintasan 4 merupakan penggabungan titik sounding $15,16,17,18$ seperti pada gambar 5

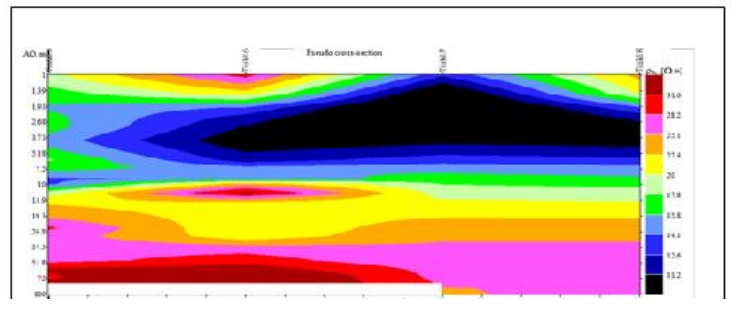

Gambar 5 Hasil pengolahan IP2WIN di lintasan 4 terdiri dari titik sounding 15, 16, 17 dan 18

Gambar 5 merupakan hasil pengolahan data denga software IP2WIN lintasan 4 pada titik sounding 15 sampai pada titik sounding 18 . Daerah yang diduga sebagai akuifer airtanah dengan nilai resistivitas 31,6 $\Omega \mathrm{m}$ citra warna merah pada kedalaman 10 meter titik sounding 16 merupakan lapisan batuan tipis yanh diakibatkan oleh rembesan air yang mengalir dari lapisan tanah sebelumnya. Titik sounding 15 dan 16 memiliki citra warna kuning, oranye dan abu - abu yang merupakan bagian dari lapisan berporos sehingga meloloskan air meresap ke titik sounding 16 dan 17 dengan memperhatikan kedalaman 13 sampai 19 meter berpeluang terdapat airtanah dan diduga memiliki kemampuan meloloskan air kelapisan selanjutnya dengan kemampuan yang besar. Titik sounding 16, 17 dan 18 dengan memperhatikan citra warna hitam dan biru memiliki jenis batuan lempung dan lempung basah yang diduga bersifat jenis lapisan yang lembab. Citra warna hitam pada titik 16 sampai 18 merupakan lapisan kedap air dengan debit air yang paling besar dari gabungan titik pada lintasan yang lain. Hal ini disebabkan karena pengambilan data pada titik 16, 17 dan 18 adalah daerah rawa. Keadaan akuifer airtanah di lintasan ini di dukung oleh keadaan titik 17 dan 18 yang merupakan daerah rawa dan terdapat sumur air denga kedalaman 2 meter di jurusan matemetika (sumur air 2) dan kedalaman 1.5 meter pada jurusan fisika (sumur 3).

\section{Pengolahan Data Lapangan Dengan Surfer 8}

Data koordinat (lintang dan bujur) setiap titik Sounding dan data kedalaman dari hasil pengolahan dengan software IP2WIN kemudian diolah dengan software 
surfer 8 untuk mendapatkan gambar 3 dimensi. Gambaran 3 dimensi ini akan menunjukkan struktur kedalaman nilai resistivitas masing - masing titik sounding serta mampu menentukan kedalaman sumber lapisan akuifer yang ada di Fakultas MIPA dan Fakultas Pertanian Unsrat.

Susunan kontur resistivitas berdasarkan kedalaman lapisan akuifer airtanah dangkal permukaan dan dangkal dalam keseluruhan titik sounding hasil pengolahan dengan software surfer 8 terlihat seperti gambar 6 .

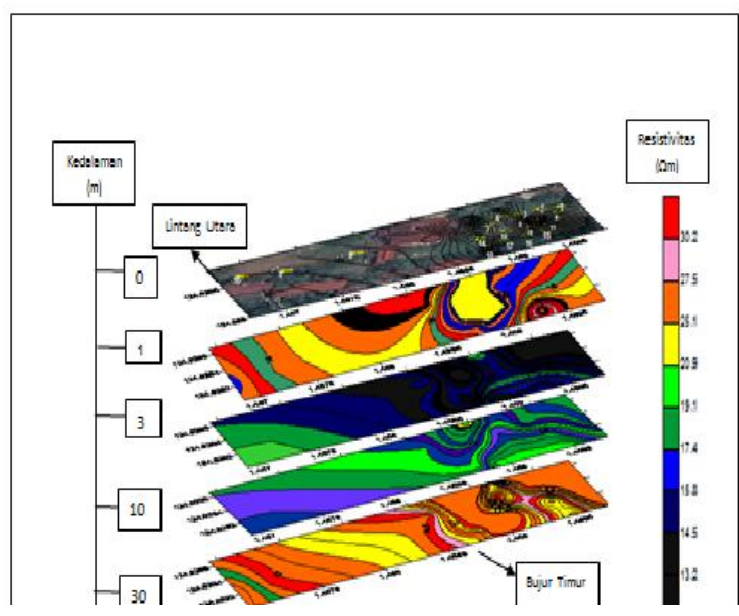

Gambar 6 Kontur resistivitas pada kedalaman tertentu dengan menggunakan software Surfer 8

Gambar 6 menunjukkan keberadaan air pada lapisan tanah pada kedalaman $1 \mathrm{~m}, 3 \mathrm{~m}$, $10 \mathrm{~m}$, dan $30 \mathrm{~m}$. Keberadaan akuifer air terlihat banyak terdapat pada lapisan dengan kedalaman $3 \mathrm{~m}$ dengan citra warna hitam ( nilai resistivitas lebih kecil dari 14,5 $\Omega \mathrm{m}$ ), yaitu lapisan dibawah permukaan pada FMIPA dan lapangan. Kemudian keberadaan air menghilang pada lapisan dengan kedalaman $10 \mathrm{~m}$, hanya terdapat pada daerah yang kecil saja yaitu pada titik 4. Untuk selanjutnya pada lapisan yang lebih dalam tidak terindikasi adanya pembawa akuifer air, hal ini ditunjukkan pada lapisan dengan kedalaman $30 \mathrm{~m}$ mempunyai resistivitas lebih besar dari $20 \Omega \mathrm{m}$ yang diduga sebagai lapisan kedap air.

\section{KESIMPULAN DAN SARAN}

\section{Kesimpulan}

1. Telah dipetakan keberadaan lapisan akuifer airtanah di Jl. Kampus Selatan Kecamatan Sario Kota Manado, Sulawesi Utara yang terletak di FMIPA UNSRAT, Fakultas Pertanian dan sekitarnya yang terletak pada koordinat $\left(1^{\circ} 27^{\prime} 34,20-1^{\circ} 27^{\prime} 25,40^{\prime \prime}\right) \mathrm{LU}$ dan (12449'44,94', - 12449'47,93'")BT.

2. Lapisan akuifer airtanah (lebih kecil dari $\rho \quad 14,5 \Omega \mathrm{m}$ ) hanya sampai kedalaman 10 meter pada daerah FMIPA dan lapangan bola UNSRAT diinterpretasikan sebagai jenis batuan tufa pasiran.

\section{Saran}

1. Pemetaan airtanah sebaiknya dilakukan dengan memperbanyak titiksounding agar mendapatkan hasil pemetaan yang lebih akurat dari setiap titik sounding.

2. Daerah pada titik sounding perlu dilakukan pengeboran untuk mendapatkan data geologi yang baik.

\section{DAFTAR PUSTAKA}

Adriyani, S., A.H Ramelan., and Sutarno. 2010. Metode Geolistrik Imaging Konfigurasi Dipole - dipole Digunakan untuk Penelusuran Sistem Sungai Bawah Tanah pada KawasanKarst di Pacita Jawa Timur. Universitas Sebelas Maret Surakarta. Surakarta

Minarto, E. 2011. Pemodelan Inversi Data Geolistrik untuk Menentukan Struktur Perlapisan Bawah Permukaan Daerah Panas Bumi Mataloko. FMIPA ITS. Surabaya Geologi untuk Perencanaan.Batuan. Yogyakarta

Hadi, I.A., Suhendra., and A. Robinson. 2009. Survei Sebaran Airtanah Dengan Metode Geolistrik Tahanan Jenis Konfigurasi Wenner Di Desa Banjar Sari, Kecamatan Enggano, Kabupaten Bengkulu Utara. F-MIPA Universitas Bengkulu, Indonesia.

Halik, G., and J. Widodo. 2008. Pendugaan Potensi Airtanah Dengan Metode Geolistrik Konfigurasi 
Schlumberger Di Kampus Tegal Boto Universitas Jember. Fakultas Teknik Universitas Jember.

Irjan. 2012. Pemetaan Potensi Airtanah (Akuifer) Berdasarkan Interpretasi Data Resistivitas Wenner Sounding. Fakultas Sains dan Teknologi UIN Maliki Malang.

Poedjoprajitno, S. 2009. Evolusi Bentuk Lahan Daerah Manado dan Sekitarnya, Sulawesi Utara. Jurnal Geologi Indonesia. $4: 2$

Putranto,T.T., and K.I. Kusuma. 2009. Permasalahan Airtanah Pada Daerah Urban. Jurnal Teknik. $30: 1$

Sadjab, B 2012. Pementaan Akuifer Airtanah di Kecamatan Prambanan Kabupaten Sleman Daerah Istimewa Yogyakarta Dengan Metode Geolistrik Tahanan Jenis.FMIPA Universitas Sam Ratulangi Manado.

Wahyudi. 2001. Panduan Workshop Eksplorasi Geofisika (Teori dan Aplikasi) FMIPA UGM, Yogyakarta. 